
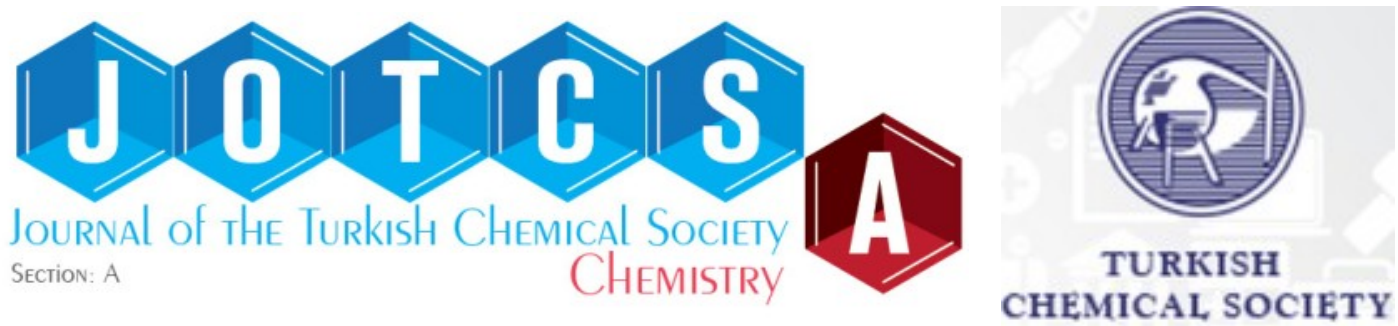

\title{
New distribution areas of Angelica tatianaeBordz and study of their coumarin derivatives
}

\author{
Husniya Mammadova Gara ${ }^{*} \square$ D and Mashayeva Sevil Saleh ${ }^{2}$ \\ ${ }^{1}$ Department of Chemistry and Biology, Sumgait State University,Sumgait, Azerbaijan \\ ${ }^{2}$ Azerbaijan National Academy of Sciences, Institute of Polymeric Materials, Sumgait, Azerbaijan
}

\begin{abstract}
The Angelica L. genus belongs to Umbelliferae family. Angelica tatianaeis very rare in Azerbaijan. In Azerbaijan so far, there has been no research about phytochemistry of $A$. tatianae. In the present study, phytochemicals of the plant have been isolated and their structures have been elucidated. The roots of Angelica tatianae Bordz were extracted with $95 \%$ alcohol and the contents were extracted of a total of 3 individual substances by chromatography in a glass column filled with $\mathrm{Al}_{2} \mathrm{O}_{3},\left(1 . \mathrm{C}_{13} \mathrm{H}_{10} \mathrm{O}_{5}, \mathrm{~m}\right.$. p. $148.0^{\circ} \mathrm{C}$; 2. $\mathrm{C}_{9} \mathrm{H}_{6} \mathrm{O}_{2}$, m.p. $67.0-68.0{ }^{\circ} \mathrm{C}$; $\quad$ 3. $\mathrm{C}_{12} \mathrm{H}_{8} \mathrm{O}_{4}$, m.p. $145.0-146.0{ }^{\circ} \mathrm{C}$ ). Based on chemical and spectral results (FTIR, ${ }^{1} \mathrm{H} N \mathrm{NMR},{ }^{13} \mathrm{C} N \mathrm{NMR}$ ), the obtained substances were identified with isopimpinellin, coumarin, and xanthotoxin, respectively.
\end{abstract}

Keywords: Angelica tatianae, chromatography, coumarin, xanthotoxin, isopimpinellin.

Submitted: January 01, 2020. Accepted: July 17, 2020.

Cite this: MAMMADOVA GARA H, MASHAYEVA SS. New distribution areas of Angelica tatianaeBordz and study of their coumarin derivatives. JOTCSA. 2020;7(3):745-52.

DOI: https://doi.org/10.18596/jotcsa.668971.

*Corresponding author. Email: husniyamammadova63@gmail.com

\section{INTRODUCTION}

There are nearly 4500 kinds of plants in the flora of Azerbaijan. Among these plants, Apiaceae Lindl's family takes a special place. This family is represented in the world with 400 genders. Among the genders including this family, Angelica L. Gender attracts attention for its specific features. There are 115 types of this gender in the world (plant list 2013, 115), (plant list 2018, 116) (1).

There are more than 50 types of Angelica species in the Caucasus. In the floraof Azerbaijan, Angelica L. gender is represented with 3 types: A.sachokiana, Angelica purpurascens and Angelica tatianae Bordz $(2,3)$. The first of them, $A$. sachokiana, is described in Azerbaijan (Ismailly, Nialdag, Kuzun village of Gusar region) $(4,5)$. It is encountered in the middle and upper mountain ranges of Greater Caucasus region on the rocks, on the banks of mountain rivers. The second $A$. purpurascens is the subalpine meadows plant of Nakhchivan and the Small Caucasus region) (6). The third type A.tatianae is encountered in the forest areas upper mountain ranges of the Small Caucasus region (Gadabay region). It is also encountered in the western part of the Greater Caucasus region (Zakhatala region) in upper mountain ranges. On our part, we found that in the small and medium range of the Lesser Caucasus (Gadabay region) is distributed in a limited range of forest areas.

A.tatianae is a rare species in the flora of Azerbaijan. This species is a remarkable perennial plan. The lifespan of the plant is 7 years. It is a monocarpous plant. It blooms in the last year, forms seeds and dies.

A.tatianae is a very valuable medicinal plant with 1$1,5 \mathrm{~m}$ height and an empty stem. It passes to the blooming phase in July with white flowers. The length of the petals is about $1-2 \mathrm{~mm}$. The columns are short cone-shaped. The column is much longer than under columns and they are folded.The flowers turn whitish-yellow as they grow. 
The length of the umbrellas consists of various, roughly 25-35 rays. The petals are white and are gathered in the umbrella flower group. The sizes of the edge and middle flowers are different. The grown seeds are wide oval-shaped, backbones are narrow, from sides are large winged, above is naked. The length of the seed is $10 \mathrm{~mm}$; the width is $5-6 \mathrm{~mm}$ and consists of ribs. The seed has a specific dark smell.

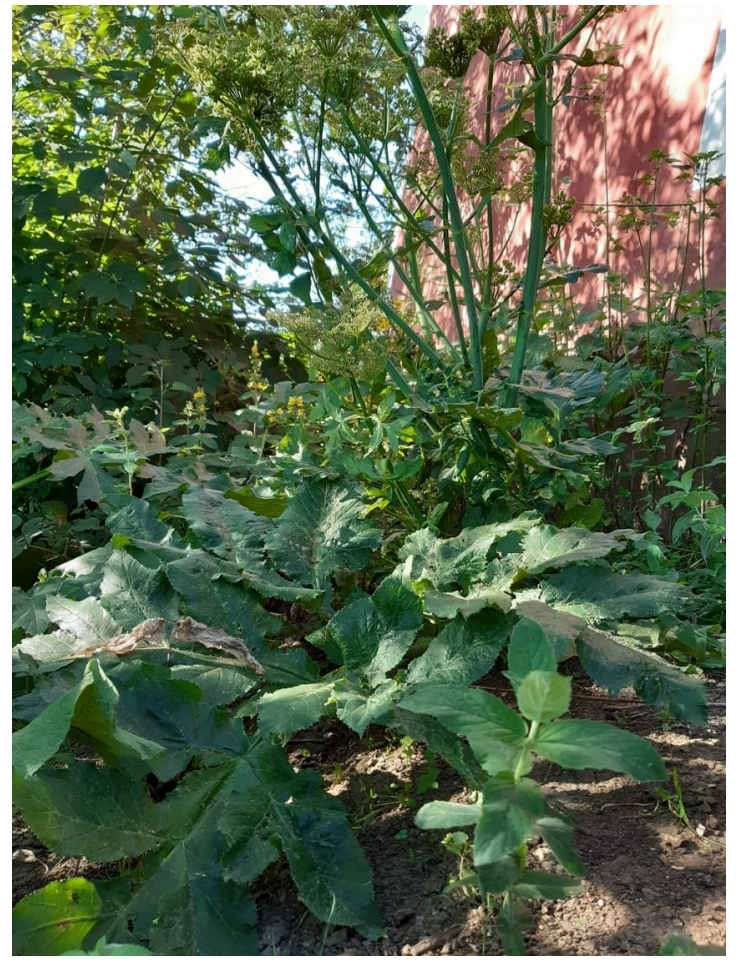

Picture 1-2. A.tatianae flowering phase (July).

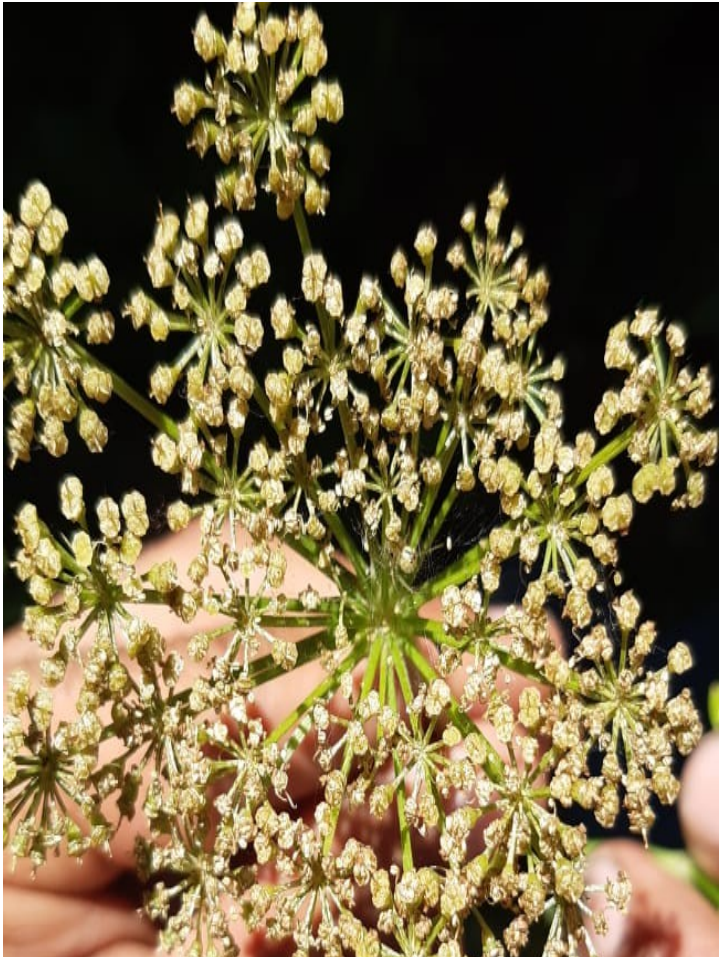

The phytochemistry of $A$. tatianae has not been studied in Azerbaijan. We first obtained isopimpinellin, coumarin and xanthotoxin from the roots of the plant. Isopimpinellin and xanthotoxin derived from plant roots belong to the class of furanocoumarins $(8,9,24,25)$.

\section{MATERIALS AND METHOD}

A. tatianae was collected from the Gadabay region in July 2013 and was assigned to the Institute of Botany of the Azerbaijan National Academy of Sciences (compared to herbariums in the herbarium fund). On July 28, 2018, the plant was re-collected from a forest area at an altitude of $2000 \mathrm{~m}$ above sea level and phytochemical studies were conducted.The bio-ecological features of the species have been studied by us. In addition, we studied the antimicrobial activity of $A$. tatianae and the repellent effect of the extract of $A$. tatianae on the mosquito Culex pipiens molestus (15-17).

Coumarins are widely spread in types of Apiaceae, especially in the genus Angelica L. (18-23). 


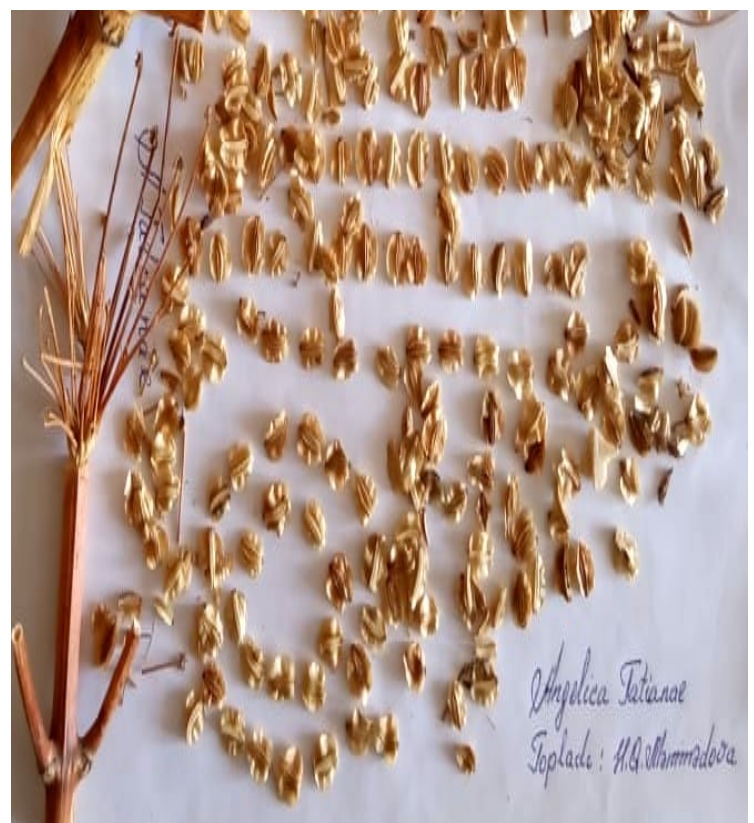

Picture 3. Seeds of A.tatianae

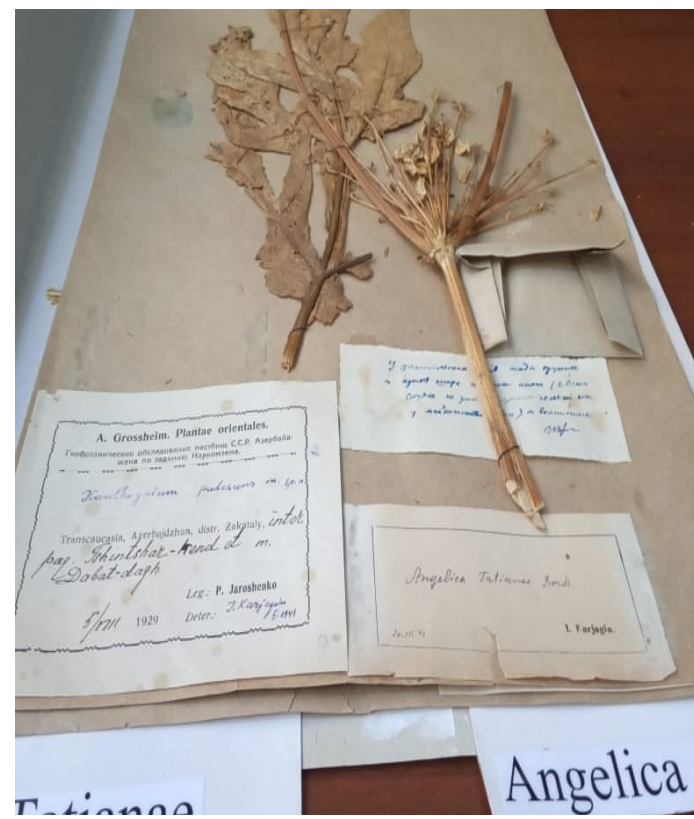

Picture 4. Photo from the herbarium fund of the Institute of Botany (A.tatianae)

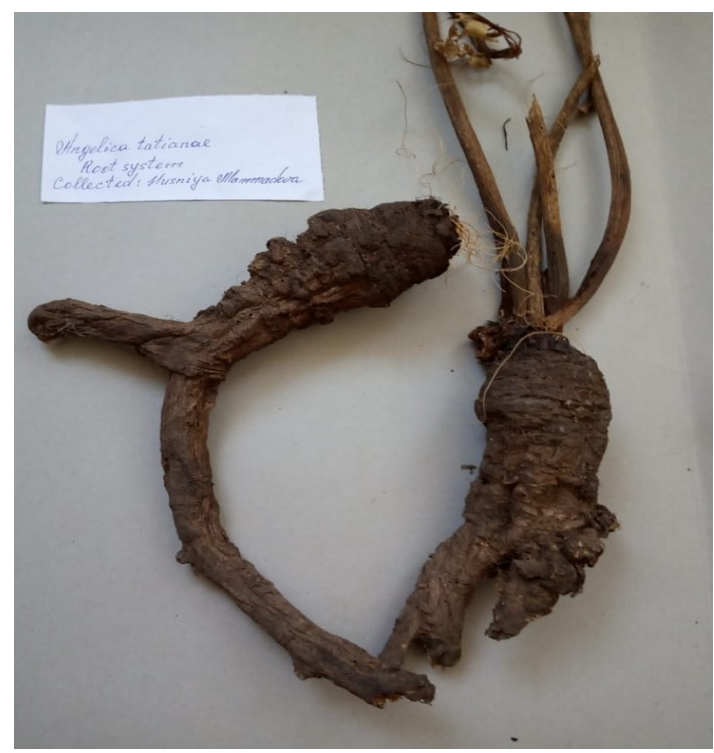

Picture 5. A. tatianae (root).

After the root of the plant was finely chopped and dried $(120 \mathrm{~g}$ ), it was extracted 3 times (each time for three days) in alcohol. Obtained the substance mixture (extract) $(17 \mathrm{~g})$ was used. Thus, substance mixture was chromatographed in a glass column $(\mathrm{h}=100 \mathrm{~cm}, \mathrm{~d}=3 \mathrm{~cm})$ that was filled with $\mathrm{Al}_{2} \mathrm{O}_{3}$. The mixture of substances we mean benzene $+\mathrm{n}$ hexane (3: 1), chloroform + ethanol (4: 1), and other mixtures used in chromatography.

The volume of each fraction is $100 \mathrm{~mL}$. Chromatography column was digitalized with nhexane (46 fractions), n-hexane+benzene (42), benzene (20 fractions), benzene+chloroform ( 23 fractions), chloroform+benzene (20 fractions),

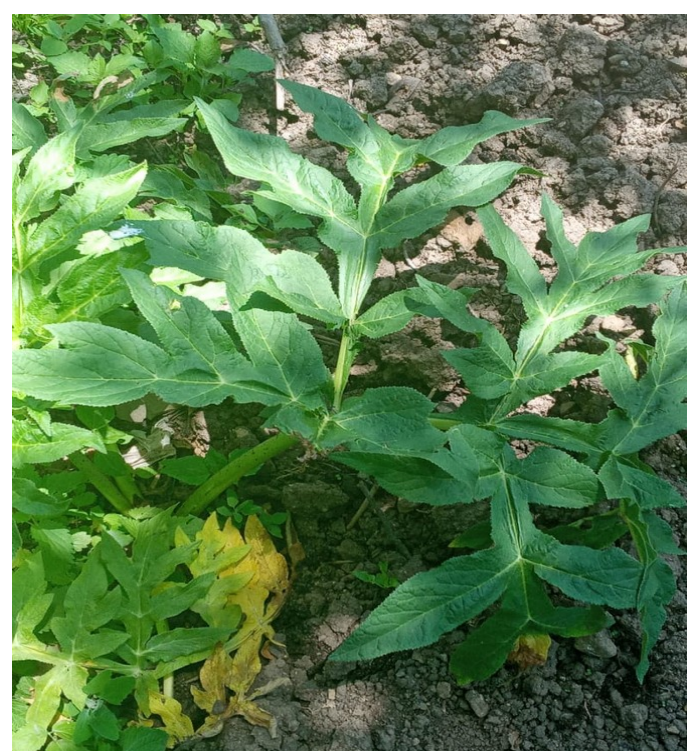

Picture 6. A. tatianae (surface part).

chloroform (28 fractions), chloroform+alcohol (6 fractions). The individuality of the substances was determined by using a thin layer chromatography method (Silifol UV254, solventbenzene+chloroform, 1:1), the melting temperature was defined on Boytius table. IG spectrums were recorded by the UR-20 spectrophotometer in Vaseline oil and the chemical structure of coumarin derivatives was defined on the base of the results obtained from the detection of NMR spectra.

\section{RESULTS AND DISCUSSION}

Three substances were extracted from chromatography of extracts from the root system of 
A.tatianae. The structures of matter are determined chemically and spectrally.

The thin layer chromatography method was used to determine the individuality of the substances derived from the root of the plant, which has been identified as substances isopimpinellin, coumarin, xanthotoxin. All 3 substances were identified with based on the results of the detection of IR and NMR spectra (7).

Coumarin and its derivatives were obtained from the roots of the plant and identified (Table 1 ). As can be seen from the table, the roots of the studied plant contained the amount of coumarin derivatives isopimpinellin $(1.356 \%)$, xanthotoxin $(1.809 \%)$ and coumarin $(3.310 \%)$.
Substance 1. Composition of the element $\mathrm{C}_{13} \mathrm{H}_{10} \mathrm{O}_{5}$, m.p. $148+C$, (Figure1). In the IR spectrum, there are absorption peaks that characterize the carbonyl $\left(1714 \mathrm{~cm}^{-1}\right)$ and double bonds $\left(1600,1649 \mathrm{~cm}^{-1}\right)$ of the lactone cycle. UV spectrum: $\lambda_{\max } 224$ (loge 4.40), 241 (loge 4.16), 268 (loge 4.26), $312 \mathrm{~nm}$ (loge 4.11). Signals detected in the $1 \mathrm{H}$ NMR are as follows: $\delta 3,96\left(\mathrm{~s}, 3 \mathrm{H}, \mathrm{OCH}_{3}\right) ; 5,23(\mathrm{~s}, 1 \mathrm{H}, \mathrm{H} 3)$; $5,99(\mathrm{~s}, 1 \mathrm{H}, \mathrm{H} 13) ; 6,13(\mathrm{~s}, 1 \mathrm{H}, \mathrm{H} 6) ; 6,80(\mathrm{~d}, 1 \mathrm{H}$, $\left.\mathrm{J}_{11,12}=8,1 \mathrm{~Hz} ; \mathrm{H} 11\right)$, e 7,13 (dd, $\mathrm{H} 1, \mathrm{~J}_{12,11}=8,1 \mathrm{~Hz}$ e $\left.\mathrm{J}_{12,8}=1,8 \mathrm{~Hz} ; \mathrm{H} 12\right)$, e $7,40\left(\mathrm{~d}, 1 \mathrm{H}, \mathrm{J}_{8,12}=1,8 \mathrm{~Hz}\right.$; $\mathrm{H} 8$ ). It is established that the substance obtained in item 1 generally refers to linear coumarin and identified as Isopimpinellin (Table 1, A) (8).

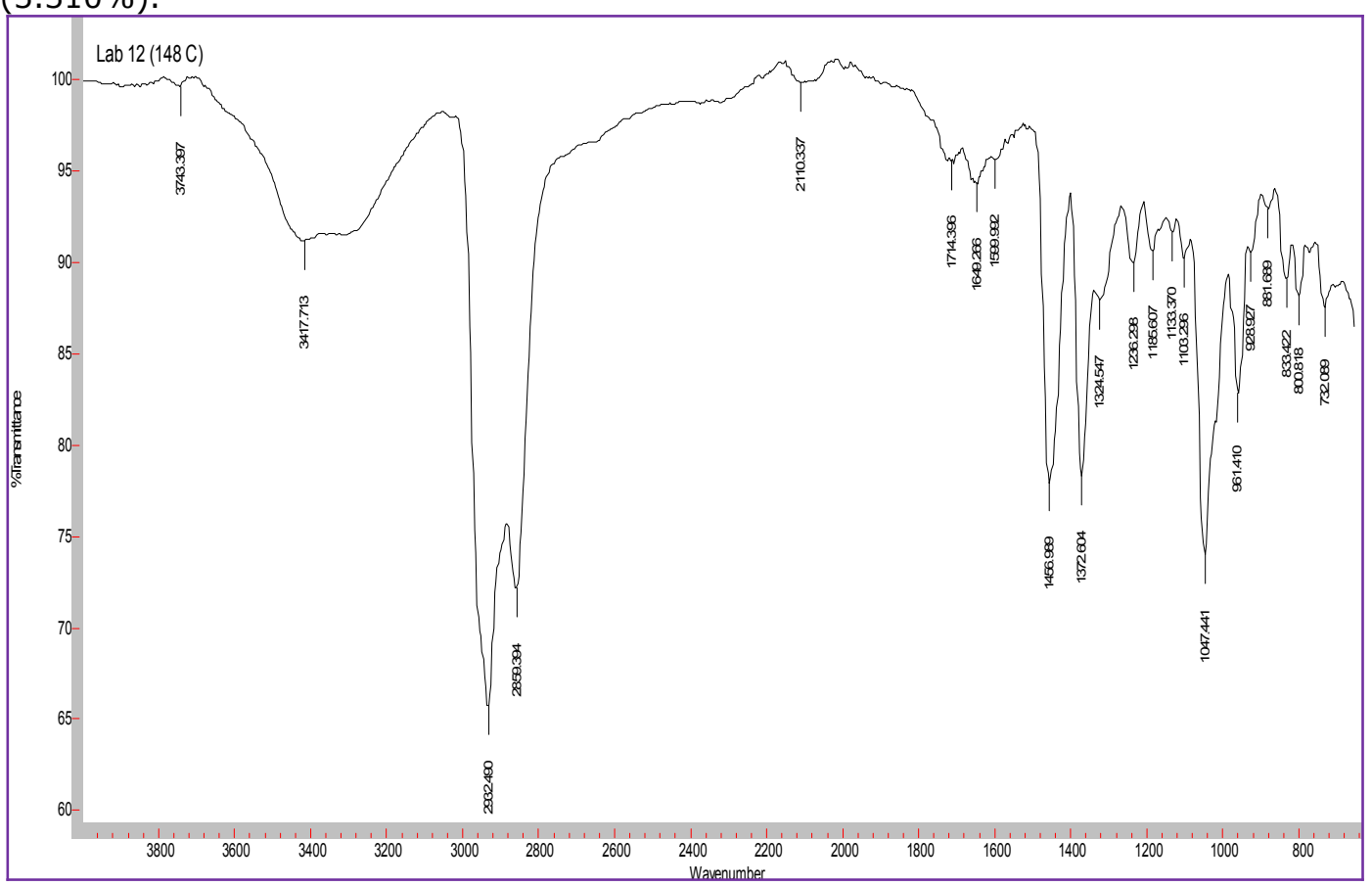

Figure 1. Composition of the element $\mathrm{C}_{13} \mathrm{H}_{10} \mathrm{O}_{5}$, m.p. $148+\mathrm{C}$.

Substance 2.The crystalline substance was extracted from the 12-16 fraction fractionated by chloroform in the chromatographic column (Figure 2). After crystallizing with ethanol + water, the elemental composition of the substance is $\mathrm{C}_{9} \mathrm{H}_{6} \mathrm{O}_{2}$. It was 67.0 - $68.0^{\circ} \mathrm{C}$. UV-spectrum: $\lambda_{\max } 275$ (loge 3.9), $325 \mathrm{~nm}$ ( $\log \varepsilon 3.75)$ In the FTIR spectrum of the substance, the $V_{\max }$ is 1723 (CO- $\delta$-lactone cycle), and $1610 \mathrm{~cm}^{-1}$ ( $\mathrm{C}=\mathrm{C}$ benzene cycle) for double bonds. Signals detected in the ${ }^{1} \mathrm{H}$ NMR spectrum of the compound: $\delta: 7.65(1 \mathrm{H}, \mathrm{d}, \mathrm{J}=9.0$ $\mathrm{Hz} \mathrm{H}-4), 7.50(2 \mathrm{H}, \mathrm{m}, \mathrm{H}-6, \mathrm{H} 7), 7.48(1 \mathrm{H}, \mathrm{d}, \mathrm{J}=$ $8.5 \mathrm{~Hz}, \mathrm{H}-8), 7.20(1 \mathrm{H}, \mathrm{d}, \mathrm{J}=8.5 \mathrm{~Hz}, \mathrm{H}-5), 6.40$ $(1 \mathrm{H}, \mathrm{d}, \mathrm{J}=9.4 \mathrm{~Hz} \mathrm{H}-3)$. The obtained formula 2 proves that the structural formula of coumarin is the same as the structure formula were identified(Table 1, B)(8). 


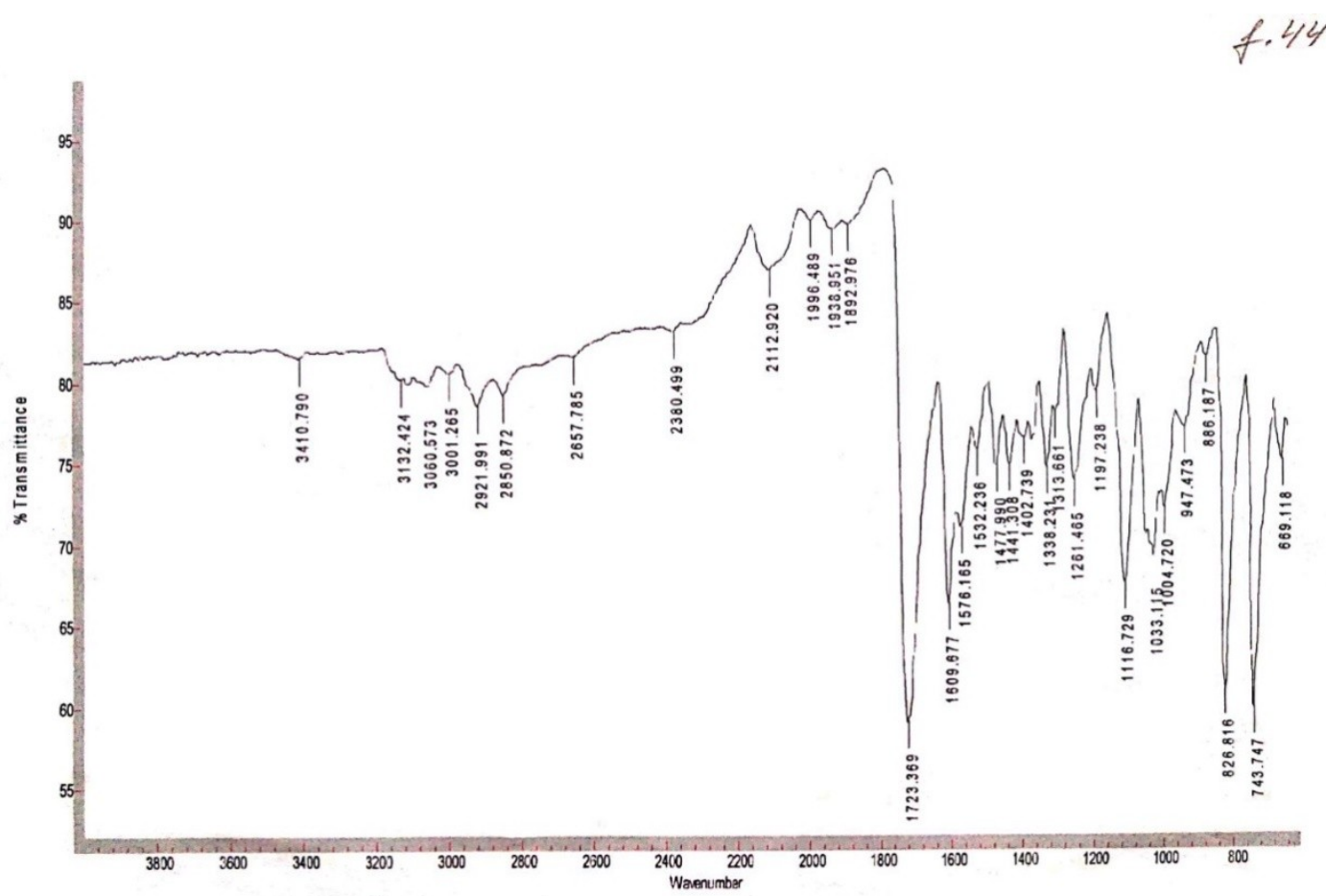

Figure 2. Composition of the element $\mathrm{C}_{9} \mathrm{H}_{6} \mathrm{O}_{2}$, m.p. $67.0-68.0{ }^{\circ} \mathrm{C}$.

Substance 3. Composition of the element $\mathrm{C}_{12} \mathrm{H}_{8} \mathrm{O}_{4}$ 145.0-146.0 ${ }^{\circ} \mathrm{C}$ (Figure 3). In the IR spectrum, the absorption peaks of the $\delta$-lactone cycle $C=0$ group $\left(1726 \mathrm{~cm}^{-1}\right)$ and the double bonds of the aromatic system $\left(1624,1594,1550 \mathrm{~cm}^{-1}\right)$ indicate that the compound belongs to the furocoumarin group. Signals detected in the ${ }^{1} \mathrm{H}$ NMR spectrum of matter: $7.73(\mathrm{~d}, \mathrm{~J}=9.65 \mathrm{~Hz}, 1 \mathrm{H}, \mathrm{CH}=, \mathrm{H}-4), 7.60$ (d. J = $2,00 \mathrm{~Hz}, 1 \mathrm{H}, \mathrm{CH}=, \mathrm{H}-3$ ') 7.32 (s., $1 \mathrm{H}, \mathrm{CH}=, \mathrm{H}-5$ ), 6.80 (d., J $=2,00 \mathrm{~Hz}, 1 \mathrm{H}, \mathrm{CH}=, \mathrm{H}-2$ '), 6.30 (d., J $=9.65 \mathrm{~Hz}, \mathrm{H}-3)$, and $3,4 \mathrm{~m}$ singlet proves the presence of methoxy $\left(-\mathrm{OCH}_{3}\right)$ group in the molecule. The substance obtained was identified as xantotoxin(Table 1, C)(9).

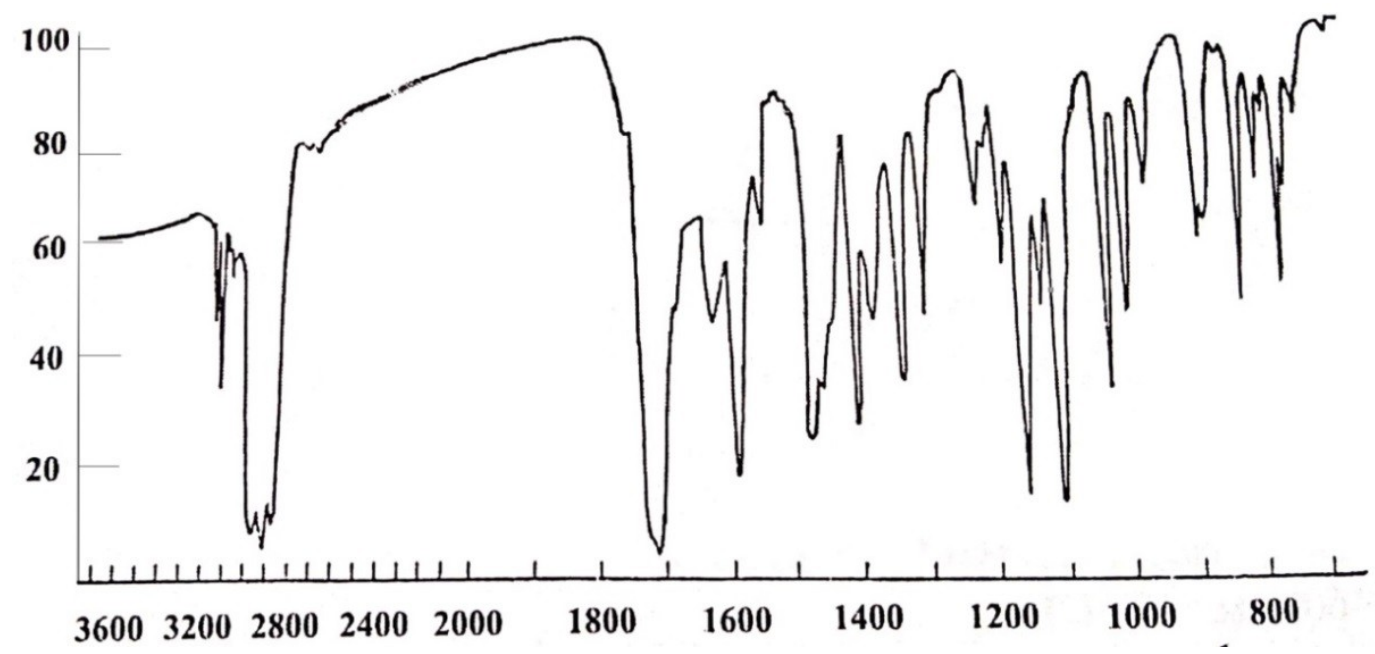

Figure 3. Composition of the element $\mathrm{C}_{12} \mathrm{H}_{8} \mathrm{O}_{4}, 145.0-146.0{ }^{\circ} \mathrm{C}$. 
Table 1. Angelica tatianae Bordz. chemical composition of the species.

B. Coumarin,

Isopimpinellin possibly inhibits 7,12dimethylbenz(a)anthracene, which is the initiator of skin tumors. Evidence has also been reported that links these compounds to the inhibition of breast cancers. Isopimpinellin has inhibitory activity against the enzyme adenine phosphoribosyltransferase (APRT) from Leishmania, a tropical parasite causing endemic disease in poor countries (10).

The coumarins are of great attention due to their therapeutic property. Their physiological, bacteriostatic and anti-tumor activity marks coumarins as novel ones for therapeutic applications. Several researchers have reported the clinical applications of coumarins and their derivatives in the treatment of several diseases. Several studies have proven multiple potential roles of coumarins which include disease spread and prevention, growth modulation, antioxidant and anti-tumor effects (12).

Xanthoxin belongs to the group of medicines called psoralens. It is used along with ultraviolet light (found in sunlight and some special lamps) in a treatment called PUVA to treat vitiligo, a disease in which skin color is lost, and psoriasis, a skin condition associated with red and scaly patches (11). Xanthoxin is also used with ultraviolet light in the treatment of white blood cells. This treatment is called photopheresis and is used to treat the skin problems associated with mycosis fungoides, which is a type of Iymphoma.

Isopimpinellin, coumarin, and xanthotoxin were first extracted from the substances investigated in the root of the Angelica tatianae plant; need further research and investigations to find out new areas of application.

\section{REFERENCES}

1. www.theplantlist.org,The Plant List, 115 (2013), The Plant List, 116 (2018).

2. Askerov AM. Higher plants of Azerbaijan. Abstract flora of Azerbaijan. 2005;1.

3. I. I. Karyagin, Flora of Azerbaijan, Genus Heracleum L., Vol. 6, 1953, p. 495.

4. H.A. Imanli, S.V. Serkerov Study of coumarin derivatives of roots and overground Parts of Angelica Sachokiana by the Chromato-MassSpectroscopy Method. News of ANAS (biology and medical scienses), Vol.70, 2015, p.15-20. Bio və Tibb Elmləri [Internet]. [cited 2020 Jul 19]. 
Available

from: http://www.jbio.az/en/journal/article/241

5. Azimova SS, Yunusov MS, editors. Natural Compounds: Alkaloids [Internet]. New York: Springer-Verlag; 2013 [cited 2020 Jul 19]. Available from:

https://www.springer.com/gp/book/978146140559 $\underline{7}$

6.Geidarov I, Serkerov S. Coumarins from Roots of Angelica purpurascens. Chemistry of Natural Compounds. $2017 ; 53$.

7. Razavi SM, Nazemiyeh $\mathrm{H}$, Hajiboland $\mathrm{R}$, Kumarasamy Y, Delazar A, Nahar L, et al. Coumarins from the aerial parts of Prangos uloptera (Apiaceae). Revista Brasileira de Farmacognosia. 2008; 18:1-5.

8. G. A. Kuznetsova, Natural Coumarins and Furocoumarins [in Russian], Leningrad (1967), p. 248.

9. Kuznetsova GA, Markelova EV, Perelson ME, Klein E, Pavlović S. (-)-3'(R)-hydroxy-4'(S)-methoxy$3^{\prime} 4^{\prime}$-dihydroxanthyletin from the roots of Peucedanum arenarium. Phytochemistry. 1978 Jan $1 ; 17(10): 1805-6$

10.Prince M, Campbell CT, Robertson TA, Wells AJ, Kleiner HE. Naturally occurring coumarins inhibit 7,12-dimethylbenz[a]anthracene DNA adduct formation in mouse mammary gland.

Carcinogenesis. 2006 Jun;27(6):1204-13.

11. Fulton JE Jr, Leyden J, Papa C. Treatment of Vitiligo With Topical Methoxsalen and Blacklite. Archives of Dermatology. 1969;100(2):224-9.

12. Lacy A, O'Kennedy R. Studies on coumarins and coumarin-related compounds to determine their therapeutic role in the treatment of cancer. Curr Pharm Des. 2004;10(30):3797-811.

13. Sokolo AI, Nikonov GK. Furocoumarins of the fruit ofXanthogalum (Angelica) tatianae. Chem Nat Compd. 1969 Jul 1;5(4):268-268.

14. Zorin EB, Ivashenko NV, Perelson ME, Pimenov MG. Coumarins from the roots of Angelica komarovii. KHIMIYA PRIRODNYKH SOEDINENII. $1984 ;(3): 388-388$.

15.H.G.Mammadova, Q.M.Verdiyeva, Bioecological features the genus Angelica tatianae of species Angelica L. spread in Dashkasan-Gadabay. Actual problems of the modern nature sciences. Vol. 2,2017May 4,(5): 63-65.

16. H.G.Mammadova, Studying of antimicrobial effect of Angelica tatianae plant extract, Azerbaijan pharmaceutical and

pharmacotherapy
17. H.G.Mammadova, M.I.Aliev, A.N.Aleskerova, P.A.Cafarova, The repellent effect of the extract of the plant Angelica tatianae Bordz on mosquitoes Culex pipiens molestus. Biology science Kazakhstan No 1,2020 , :12-17.

18. Kurbanova F, Serkerov S. A new psoralenic methoxyfurocoumarin from fruit of Heracleum transcaucasicum. Chemistry of Natural Compounds. $2012 ; 48$.

19. Lemmich J, Lemmich E, Nielsen BE. Constituents of umbelliferous plants. 8. Coumarins from the root of Seseli libanotis (L.) Koch. The structure of three new coumarins. Acta Chem Scand. $1966 ; 20(9): 2497-507$.

20. Analysis, isolation and insecticidal activity of linear furanocoumarins and other coumarin derivatives fromPeucedanum (Apiaceae: Apioideae) - PubMed [Internet]. [cited 2020 Jul 19]. Available from: https://pubmed.ncbi.nlm.nih.gov/24242727/

21. K R, Ps S. Therapeutic Role of Coumarins and Coumarin-Related Compounds. Journal of Thermodynamics \& Catalysis. $2014 ; 5(2): 1-3$.

22. Abyshev A.Z., Nguyen C.B. SYNTHETIC COVALENTLY COMBINED DERIVATIVES OF 2H-1BENZOPYRAN-2-ONE. Drug development \& registration. 2017;(4):132-138. (In Russ.)

23. Yuldashev MP, Batirov EKh, Malikov VM. Coumarin glycosides ofHaplophyllum perforatum. Chem Nat Compd. 1980 Mar 1;16(2):125-8.

24. 1987 - Volume 12, Issue 2 - FABAD Journal of Pharmaceutical Sciences [Internet]. [cited 2020 Jul 19]. Available from: http://dergi.fabad.org.tr/1987volume-12-issue-2/

25. Murray, R. D. H., J. Mendez, and S. A. Brown, The Natural Coumarins: Occurrence, Chemistry, and Biochemistry, Wiley, New York, 1982. Google Scholar 
